\author{
CEZARY KABAŁA ${ }^{1 *}$, PRZEMYSŁAW CHARZYŃSKI ${ }^{2}$, SZABOLCS CZIGÁNY ${ }^{3}$, \\ TIBOR J. NOVÁK ${ }^{4}$, MARTIN SAKSA ${ }^{5}$, MARCIN ŚWITONIAK ${ }^{2}$ \\ ${ }^{1}$ Wroctaw University of Environmental and Life Sciences, Institute of Soil Science and Environmental Protection \\ ul. Grunwaldzka 53, 50-375 Wroctaw, Poland \\ ${ }^{2}$ Nicolaus Copernicus University, Department of Soil Science and Landscape Management \\ ul. Lwowska 1, 87-100, Toruń, Poland \\ ${ }^{3}$ University of Pécs, Department of Physical and Environmental Geography \\ 6 Ifjúság u., 7624 Pécs, Hungary \\ ${ }^{4}$ University of Debrecen, Department for Landscape Protection and Environmental Geography \\ Egyetem tér 1, 4002 Debrecen, Hungary \\ ${ }^{5}$ National Agricultural and Food Centre, Soil Science and Conservation Research Institute \\ Gagarinova 10, 82713 Bratislava, Slovakia
}

\title{
Suitability of World Reference Base for Soil Resources (WRB) to describe and classify chernozemic soils in Central Europe
}

\begin{abstract}
Chernozemic soils are distinguished based on the presence of thick, black or very dark, rich in humus, well-structural and base-saturated topsoil horizon, and the accumulation of secondary carbonates within soil profile. In Central Europe these soils occur in variable forms, respectively to climate gradients, position in the landscape, moisture regime, land use, and erosion/ accumulation intensity. "Typical" chernozems, correlated with Calcic or Haplic Chernozems, are similarly positioned at basic classification level in the national soil classifications in Poland, Slovakia and Hungary, and in WRB. Chernozemic soils at various stages of their transformation are placed in Chernozems, Phaeozems or Kastanozems, supplied with respective qualifiers, e.g. Cambic, Luvic, Salic/Protosalic, Sodic/Protosodic etc. Some primeval Chernozems thinned by erosion may still fulfil criteria of Chernozems, but commonly are shifted to Calcisols. Soils upbuilt (aggraded) with colluvial additions may also retain their original placement in Chernozems, getting supplementary qualifier Colluvic. "Hydromorphic" chernozemic soils, in many CE systems are placed as separate soil type ("czarne ziemie" or "čiernice") at the same level with "typical" chernozems. Classification of these soils in WRB depends on the presence of chernic horizon, depth of secondary carbonate accumulation and depth of gleyic/stagnic properties, and may vary from Gleyic/Stagnic Chernozems/Phaeozems to Mollic Gleysols/Stagnosols. Although WRB classification differs from national classifications in the concepts and priorities of classification, it provides large opportunity to reflect the spatial variability and various stages of transformation/degradation of chernozemic soils in Central Europe.
\end{abstract}

Keywords: Calcisols, Chernozems, Gleysols, Kastanozems, Phaeozems, soil classification

\section{INTRODUCTION}

Chernozems are iconic soils for global soil science due to their special fertility and agricultural usefulness (Pozniak and Havrysh 2019). Chernozems are subjected to continuous interest of pedologists and agronomists, and, in many countries, are under legal protection as strategic reserves for national and global food security. Thus, the standardization of the inventory, evaluation and mapping of chernozems on a global scale should have a scientific priority. However, chernozem definition is based on strictly zonal concept invented by Dokuchaev and his followers, closely related to steppe vegetation, fauna and specific parent material (Eckmeier et al. 2007; Drewnik et al. 2014; Vysloužilová et al. 2016). If the properties and classification of chernozems developed in the continental steppe zones have not been questioned, there are different opinions on the origin and classification of chernozemic soils at the margins or beyond the present-day steppe zone. These inconsistencies have their source (a) in the transitional character of climate and vegetation that influence the soil forming (transforming) processes, and (b) in the subsequent changes of the environmental conditions during the Holocene period which made chernozems polygenetic soils - presently existing under different climate and vegetation than these in the time of their development and further transformation (Vysloužilová et al. 2014a, 2014b; Kabała 2019a). Also, the land use and other human impacts may greatly influence the direction and scale of chernozem evolution or degradation, sometimes shifting them to the other classification units (Kalinina et al. 2011; Lorz and Saile 2011; Zádorová et al. 2013; Alexandrovskiy et al. 2014; Novák et al. 2014; Chendev et al. 2017; Smetanová et al. 2017; Ž́žžala et al. 2019).

In general, there is continuous discussion on the extent of "zonal" chernozems in Europe and the status 
of "extrazonal" chernozems, considered to be "degraded" compared to "typical" zonal chernozems. Local classification systems may have tendency to "preserve" various chernozemic soils under the name of chernozem, even if their properties differ from these of "typical" zonal chernozems (Š́ly et al. 2000; Němeček et al. 2011; Gerasimova and Khitrov 2012; Kabała et al. 2019). To keep the soil names and maps understandable to international society it is necessary to draw the minimum requirements for chernozems, a set of absolutely necessary properties, which guarantee the uniqueness of chernozems among other chernozemic soils (Skalský et al. 2009; Zádorová and Penížek 2011).

Therefore, it is important to develop uniform international criteria and terminology for soil naming and classification. Two international classification systems theoretically offer this possibility, i.e. US Soil Taxonomy (Soil Survey Staff 2014) and WRB (World Reference Base for Soil Resources; IUSS Working Group WRB 2015). Although the Soil Taxonomy applies climatic criteria to soil classification at high level of classification, the concept of Mollisols order does not offer reliable identification of soils traditionally considered as Chernozems. The definitions of many Reference Soil Groups (RSGs) of WRB classification more clearly refer to the zonal origin and distribution of soils (Driessen et al. 2001). Three RSGs involve major variability of chernozemic soils: Chernozems, Kastanozems and Phaeozems, accompanied eventually by at least two other RSGs: Mollic Gleysols and Mollic Stagnosols. Recently, various projects have been launched to compare criteria and rules of soil classification and mapping aimed on unification of knowledge on soil resources in Europe and worldwide (Bieganowski et al. 2013; Tóth et al. 2013; International Network of Black Soils 2019). The FACES project (Freely Accessible Central European Soils, managed by Nicolaus Copernicus University of Toruń, Poland) has also created a platform for testing the suitability of WRB to properly describe and name the soils, taking into account an original soil classification in the local (national) soil classification systems in Central European countries (Świtoniak et al. 2018).

The aim of the paper is to analyse the approaches to soil naming in WRB and national soil classifications of various chernozemic soils present in Central Europe, in relation to factors of their origin or transformation, using mainly the soil profiles discussed under the FACES project (Soil Database 2019).

\section{METHODS}

Soil profiles were selected and prepared in majority during the workshops of the FACES project consortium in years 2016-2018 in various parts of Poland, Slovakia and Hungary (Fig. 1). Localization of the profiles and basic environmental characteristics for the sites are briefly summarized in table 1 . Soil horizons were distinguished and described according to modernised FAO guidelines, suited to Central European conditions (Świtoniak et al. 2018). Only the crucial soil characteristics are displayed in table 2, including the soil colour (moist), structure, consistence, texture and diagnostic horizons/properties. Samples from all distinguished horizons were collected for analysis. Particle-size distribution was determined by hydrometer or pipette method after sample dispersion with sodium hexametaphosphate. Texture class was established according to USDA classification, adopted by WRB (IUSS Working Group WRB 2015). Organic carbon content was measured by dry combustion method with spectrometric detection of released $\mathrm{CO}_{2}$ (after carbonate removal). Calcium carbonate content was analysed using volumetric method on Scheibler apparatus and soil pHw was analysed in distilled water (at soil:water ratio 1:2.5) using potentiometric method. Base saturation was calculated as the percentage ratio of the content of base cations extracted with $1 \mathrm{M}$ ammonium acetate at $\mathrm{pH} 7$ to cation exchange capacity. In general, base saturation was very high, between 81 and $100 \%$ (tab. 2), thus in some soils the analysis was omitted with an assumption that it exceeds $50 \%$, if its $\mathrm{pHw}$ is higher than 5.5 (Kabała and Łabaz 2018). Soil classification/names have been established following the WRB classification (IUSS Working Group WRB 2015) and national classifications (Stefanovits 1992; Michéli et al. 2006; Societas Pedologica Slovaca 2014; Kabała et al. 2019a), respectively to location of soil profile under investigation (fig. 2a-d).

\section{RESULTS AND DISCUSSION}

\section{Poland}

Although Poland, with its moist temperate climate, has been considered to extend beyond the continental zone, numerous spots of chernozemic soils have persisted mostly in the South Poland loess belt (Labaz et al. 2018), probably as remnants of much more extensive cover of chernozems developed in the late Pleistocene/early Holocene or in the Neolithic periods (Kabala et al. 2019b). Chernozemic soils developed from glacial tills characterized by natural poor 


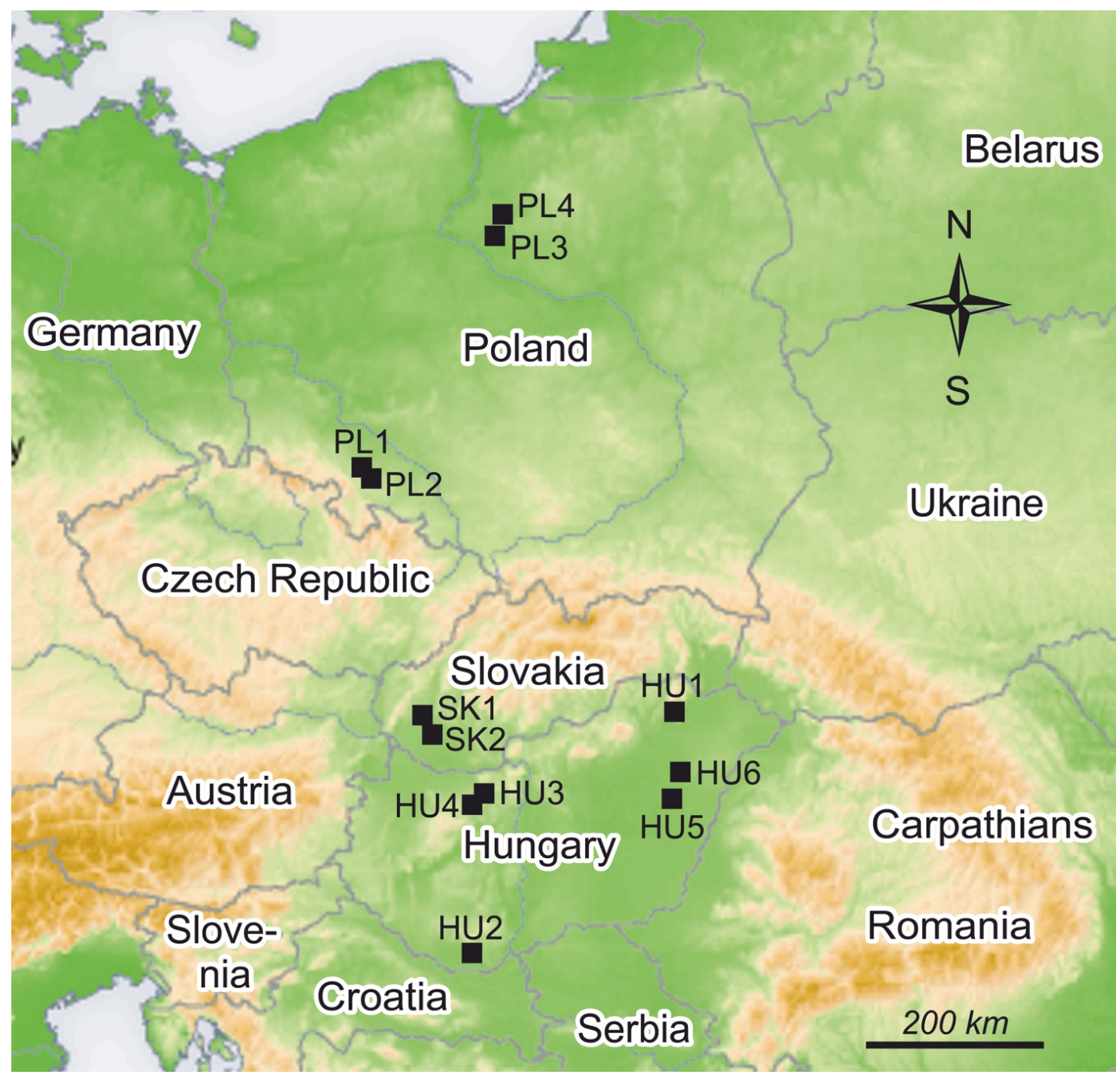

FIGURE 1. Sketch map of Central Europe with the location of soil profiles under study

drainage and waterlogging are also found on the moraine plateaus in northern Poland (Cieśla 1965; Długosz et al. 1997).

In SW Poland (the Lower Silesia region), chernozemic soils are developed in two main varieties, the naturally well-drained ("dry") and the waterlogged or artificially drained ("hydromorphic") forms. The hydromorphic forms, called in Poland black earths czarne ziemie (Łabaz and Kabała 2014), cover an extensive flat areas in the Wroclaw Plain, whereas the "dry" forms ("czarnoziemy") are present exceptionally on some gentle hill-slopes only (Kabała et al. 2015). Both "dry" and "hydromorphic" chernozemic soils are developed in SW Poland from thick loess or loess-like materials and typically have a texture of silt loam throughout the profile, or sometimes are underlain with glacial till or glaciofluvial sand (table 1 and 2; profiles PL1 and PL2). Main morphological feature is the presence of thick (50-70 $\mathrm{cm}$ and more) and darkcoloured topsoil humus horizon, that meets the criteria of mollic and chernic diagnostic horizons, following the WRB criteria (IUSS Working Group WRB 2015) for colour, thickness, structure, organic carbon content and base saturation (table 2). Soils located in flat and lower landscape positions, most often hydromorphic like PL2, have a darker, less saturated soil colour and higher organic carbon content compared to soils located in the higher landscape positions, like PL1 (table 2). The structure of humus horizon is granular (fine and medium) or blocky subangular or angular with secondary granular aggregates. The blocky subangular and angular aggregates prevail in plough horizons of soils located in lower positions, while granular aggregates prevail typically in welldrained soils of hill-slopes. These chernozemic soils typically have secondary carbonate accumulations in form of hard nodules in the profile and the resulting calcic horizon is present at various depths: in soils on slopes or elevations it typically starts below $100 \mathrm{~cm}$ from the surface, while in the soils of depressions it often starts at $50-80 \mathrm{~cm}$ (some dispersed carbonates may be present throughout the profile). The most 
TABLE 1. Profile location and outline of climate, topography and lsnd use

\begin{tabular}{|c|c|c|c|c|c|c|c|c|c|}
\hline \multirow[t]{2}{*}{ Profile ID } & \multirow[t]{2}{*}{ Location } & \multirow[t]{2}{*}{ Coordinates } & \multirow[t]{2}{*}{ Topography } & \multirow{2}{*}{$\begin{array}{l}\text { Elevation } \\
\text { m a.s.l. }\end{array}$} & \multirow{2}{*}{$\begin{array}{l}\text { MAAT } \\
{ }^{\circ} \mathrm{C}\end{array}$} & \multirow{2}{*}{$\begin{array}{l}\text { MAP } \\
\mathrm{mm}\end{array}$} & \multirow{2}{*}{$\begin{array}{c}\text { Parent } \\
\text { - material }\end{array}$} & \multirow[t]{2}{*}{ Land use } & \multirow{2}{*}{$\begin{array}{l}\text { Erosion } \\
\text { /accumulation }\end{array}$} \\
\hline & & & & & & & & & \\
\hline PL1 & $\begin{array}{l}\text { SW Poland, } \\
\text { Sudeten } \\
\text { Foreland }\end{array}$ & $\begin{array}{l}\text { N 504', } \\
\text { E } 16^{\circ} 51^{\prime}\end{array}$ & gently rolling & 166 & 8.0 & 620 & loess & arable & none \\
\hline PL2 & $\begin{array}{l}\text { SW Poland, } \\
\text { Silesian } \\
\text { Lowland }\end{array}$ & $\begin{array}{l}\text { N 50 } 59^{\prime} \\
\text { E } 16^{\circ} 56^{\prime}\end{array}$ & flat & 137 & 8.5 & 580 & $\begin{array}{l}\text { loess on } \\
\text { glacial till }\end{array}$ & arable & none \\
\hline PL3 & $\begin{array}{l}\text { NE Poland, } \\
\text { Chełmno } \\
\text { Lakeland }\end{array}$ & N 530ㅜ, & $\begin{array}{l}\text { very gently } \\
\text { rolling }\end{array}$ & 94 & 7.3 & 520 & glacial till & arable & eroded \\
\hline PL4 & $\begin{array}{l}\text { NE Poland, } \\
\text { Brodnica } \\
\text { Lakeland }\end{array}$ & $\begin{array}{l}\text { N 53ํㅇ' } \\
\text { E } 19^{\circ} 18^{\prime}\end{array}$ & gently rolling & 89 & 6.8 & 550 & $\begin{array}{l}\text { colluvium } \\
\text { on glacial } \\
\text { till }\end{array}$ & arable & accumulation \\
\hline SK1 & $\begin{array}{l}\text { SW Slovakia, } \\
\text { Danube } \\
\text { Lowland }\end{array}$ & $\begin{array}{l}\text { N } 48^{\circ} 17^{\prime} \\
\text { E } 17^{\circ} 33^{\prime}\end{array}$ & flat & 139 & 10.0 & 500 & loess & arable & none \\
\hline SK2 & $\begin{array}{l}\text { SW Slovakia, } \\
\text { Danube } \\
\text { Lowland }\end{array}$ & $\begin{array}{l}\text { N } 48^{\circ} 17^{\prime} \\
\text { E } 21^{\circ} 22^{\prime}\end{array}$ & gently sloping & 426 & 9.0 & 580 & $\begin{array}{l}\text { loess on } \\
\text { pyroclasti- } \\
\text { cs }\end{array}$ & $\begin{array}{l}\text { secondary } \\
\text { forest }\end{array}$ & none \\
\hline HU1 & $\begin{array}{l}\text { NE Hungary, } \\
\text { Tokaj-Hill }\end{array}$ & $\begin{array}{l}\mathrm{N} 48^{\circ} 07^{\prime} \\
\mathrm{E} 21^{\circ} 22^{\prime}\end{array}$ & gently sloping & 426 & 9.0 & 580 & $\begin{array}{l}\text { loess on } \\
\text { pyroclastics }\end{array}$ & $\begin{array}{l}\text { secondary } \\
\text { forest }\end{array}$ & none \\
\hline HU2 & $\begin{array}{l}\text { SW Hungary, } \\
\text { Baranya Hills }\end{array}$ & $\begin{array}{l}\text { N } 46^{\circ} 02^{\prime} \\
\text { E } 18^{\circ} 03^{\prime}\end{array}$ & flat & 132 & 11.0 & 610 & loess & arable & none \\
\hline HU3 & $\begin{array}{l}\text { Central } \\
\text { Hungary } \\
\text { Mezőföld } \\
\end{array}$ & $\begin{array}{l}\text { N } 47^{\circ} 19^{\prime} \\
\text { E } 18^{\circ} 47^{\prime}\end{array}$ & flat & 119 & 10.6 & 560 & loess & arable & none \\
\hline HU4 & $\begin{array}{l}\text { Central } \\
\text { Hungary, } \\
\text { Mezőföld }\end{array}$ & $\begin{array}{l}\text { N } 47^{\circ} 19^{\prime} \\
\text { E } 18^{\circ} 47^{\prime}\end{array}$ & flat & 113 & 10.6 & 560 & loess & arable & eroded \\
\hline HU5 & $\begin{array}{l}\text { E Hungary, } \\
\text { Nagy-Sárrét }\end{array}$ & $\begin{array}{l}\mathrm{N} 47^{\circ} 17^{\prime} \\
\mathrm{E} 21^{\circ} 15^{\prime}\end{array}$ & flat & 91 & 10.5 & 530 & $\begin{array}{l}\text { fluvial silt- } \\
\text { clay }\end{array}$ & garden & none \\
\hline HU6 & $\begin{array}{l}\text { E Hungary, } \\
\text { Hortobágy }\end{array}$ & $\begin{array}{l}\mathrm{N} 47^{\circ} 34^{\prime} \\
\text { E } 21^{\circ} 15^{\prime}\end{array}$ & flat & 89 & 10.5 & 530 & $\begin{array}{l}\text { loess on } \\
\text { fluvial silt- } \\
\text { clay }\end{array}$ & grassland & none \\
\hline
\end{tabular}

important morphological difference between "dry" and "hydromorphic" chernozemic soils is the presence of a well-expressed gleyic or stagnic properties in the bottom and sometimes also in a middle part of "hydromorphic" chernozemic soil profile. Whereas, the well-drained ("dry") chernozemic soils do not have gleyic or stagnic properties at all, or have it very poorly expressed.

According to the Polish Soil Classification (Kabata et al. 2019a), soils having a mollic horizon (thicker than $30 \mathrm{~cm}$ ) and secondary carbonate accumulation (comparable with calcic horizon or protocalcic properties of WRB) starting no deeper than $150 \mathrm{~cm}$ from the surface, but lacking the stagnic or gleyic properties, are classified in a chernozem type ("czarnoziemy"). These soils, in large majority, refer to Chernozems in WRB; however, may also belong to Phaeozems, if the layer with carbonate accumulation starts deeper than $50 \mathrm{~cm}$ below the mollic horizon.
Thus, the "typical chernozems" that have the secondary carbonates no deeper than $100 \mathrm{~cm}$ from the surface (following the requirements of the Polish Soil Classification) belong to Chernozems group in WRB, and the "leached chernozems" that have carbonates deeper than $100 \mathrm{~cm}$ from the soil surface, in majority belong to Phaeozems group (Kabała et al. 2019a). The soils with a thick mollic (or chernic) horizon, having high base saturation (throughout the soil profile), but featured with strong stagnic or gleyic properties belong to typical black earths (czarne ziemie typowe) after Polish Soil Classification. According to WRB, these soils refer to Gleyic/Stagnic Chernozems, as the redoximorphic features, if present deeper than $40 \mathrm{~cm}$ from the surface, are less important in WRB scheme than the presence of mollic/chernic horizon and secondary carbonate accumulation. In some soils located in the depressions or in other sites with imperfect drainage systems, the strong redoximorphic 
features (gleyic properties) may start less than $40 \mathrm{~cm}$ from the surface or even directly below the plough layer. In such sites, the soils with mollic horizon may be classified (according to WRB) as Mollic Gleysols (Gerasimova and Khitrov 2012), even if contain large amounts of secondary carbonates.

The above mentioned "dry" and "hydromorphic" chernozemic soils may occur even in one slope catena, in a following order (starting from the upper slope): Phaeozem (leached chernozem) - Calcic Chernozem ("typical chernozem") - Gleyic Chernozem - Mollic Gleysol (typical black earth). The main reason for this spatial variability is the natural climate humidity, which presumably turned the originally "dry" Chernozems into "hydromorphic" Chernozems (Polish "black earths") in the late Holocene period (Labaz et al. 2018; Kabała et al. 2019b). The surface relief is a factor supporting the spatial soil variability, as the concave and flat-low positioned landscape forms foster water accumulation, whereas convex landscape forms foster water drainage and also soil leaching and erosion. Accumulation of the humus-rich soil material in the foot-slopes and in the local depressions, followed by thickening of humus horizon of "moist" chernozemic soils (Gleyic Chernozem (Colluvic)) may be the other expression of spatial variability of chernozemic soils in the region (Labaz et al. 2019a); however, mostly human-driven (Zádorová et al. 2013; Świtoniak 2014).

Chernozemic soils of north Poland commonly are similar to the "hydromorphic" forms described above, in relation both to the humid climate and soil location in concave/low-positioned landscape forms. Because they occur in areas intensively used by agriculture, the soils in many places, when they are located on convex terrain positions, are often affected by erosion (profile PL3). The topsoil humus horizons of these eroded soils still fulfil criteria of mollic or chernic horizons but their thickness is restricted to the depth of ploughing - approximately $30 \mathrm{~cm}$. As a result of subsoil admixing during ploughing, calcareous material is partly incorporated into Ap horizons. As a consequence, despite the climate favourable for leaching, the topsoil chernic horizons are rich in carbonates and have a slightly lighter colour compared to non-eroded horizons (tab. 2). On the other hand, chernozemic soils located in shallow depressions and concave sections of slopes are often covered by colluvial material (PL4). These slope deposits have high $\mathrm{pH}$ values, are relatively rich in organic carbon, have dark colour and well developed granular or fine subangular soil structure, thus may meet criteria for mollic horizon. Whereas, the buried native humus horizons may meet criteria for chernic horizon (tab. 2). Because of the presence of strong redoximorphic features, the two soil variants under comparison in north Poland (both the eroded and covered by colluvial material) are classified as black earths according to Polish Soils Classification (Kabała et al. 2019a). According to WRB (IUSS Working Group WRB 2015), the soil PL3, although eroded, still meets the criteria of Calcic Chernozems, and soil PL4 belongs to Eutric Chernic Gleysols (Colluvic).

\section{Slovakia}

Similarly like in other Central European countries, in Slovakia are also distinguished two varieties of chernozemic soils differing in moisture regime, i.e. "dry" or well-drained černozeme and "hydromorphic" čiernice - black earths (Societas Pedologica Slovaca 2014). Both forms occur mainly in Danube lowland in the southwest of Slovakia. Čiernice are common mainly on Danube flat land, on loess sediments in mixture with loamy calcareous alluvial deposits, while černozeme occur mainly in Danube hilly lands dominantly constructed from loess. Černozeme in SW Slovakia are developed from loess and loess-like materials, have a loamy or silt-loamy texture and secondary carbonates accumulation starting within the upper $100 \mathrm{~cm}$ of soil. The topsoil humus horizon often fulfil the criteria for chernic horizon according to WRB (IUSS Working Group WRB 2015), thus soils typically meet the requirements for Calcic Chernozems (tab. 2; profile SK1).

The development of these chernozems began with the formation of chernic/mollic horizons under steppe vegetation during the Boreal period of Holocene (Hraško 1966). During the Atlantic period, the warmest and most humid period of Holocene, the steppe was presumably replaced with broadleaf forests (Krippel 1986). The soils were exposed to higher precipitation and leaching of carbonates under forest vegetation (under beech forests in particular) resulting in decalcification of the upper part of the soil profile. Decalcification and permanent forest cover have encouraged further processes, such as weathering, clay translocation and decomposition of soil organic matter. The chernic/mollic horizon became thinner and poorer in humus, and illuvial argic horizons have formed (table 2; profile SK2). These transformed humus horizons very often do not fulfil the criteria for mollic horizon according to WRB (IUSS Working Group WRB 2015) and Slovak classification system (Societas Pedologica Slovaca 2014), thus soil have to be classified as Luvisols (Luvizeme in Slovak). The existence of transitional forms of the Luvic Chernozems/Kastanozems is also possible. 
TABLE 2. Soil morphology, physicochemical properties, diagnostic horizons and properties

\begin{tabular}{|c|c|c|c|c|c|c|c|c|c|c|c|}
\hline \multirow{2}{*}{$\begin{array}{l}\text { Profile } \\
\text { ID }\end{array}$} & \multirow[t]{2}{*}{ Horizon } & \multirow{2}{*}{$\frac{\text { Depth }}{\mathrm{cm}}$} & \multirow{2}{*}{$\begin{array}{l}\text { Colour } \\
\text { (moist) }\end{array}$} & \multirow[t]{2}{*}{ Structure } & \multirow{2}{*}{$\begin{array}{l}\text { Consi- } \\
\text { stence }\end{array}$} & \multirow{2}{*}{$\begin{array}{l}\text { Texture } \\
\text { class }\end{array}$} & \multirow{2}{*}{$\begin{array}{l}\text { TOC } \\
\%\end{array}$} & \multirow[t]{2}{*}{$\mathrm{pHw}$} & \multirow{2}{*}{$\frac{\mathrm{BS}}{\%}$} & \multirow[t]{2}{*}{$\mathrm{CaCO}_{3}$} & \multirow[t]{2}{*}{ Diagnostics } \\
\hline & & & & & & & & & & & \\
\hline \multirow[t]{5}{*}{ PL1 } & Ap & $0-26$ & 10YR $3 / 2$ & gr, $\mathrm{f}$ & vfr & $\mathrm{SiL}$ & 1.23 & 6.9 & 92 & 0 & chernic \\
\hline & $\mathrm{A}$ & $26-72$ & 10 YR $3 / 2$ & $\mathrm{gr} / \mathrm{sb}, \mathrm{f} / \mathrm{m}$ & vfr & SiL & 0.60 & 7.2 & 95 & 0 & mollic \\
\hline & $\mathrm{AB}$ & $72-93$ & 10 YR 4/4 & $\mathrm{sb}, \mathrm{f} / \mathrm{m}$ & $\mathrm{fr}$ & SiL & 0.26 & 7.6 & 100 & 0 & cambic \\
\hline & $\mathrm{BC}$ & $93-115$ & 10YR 5/8 & $\mathrm{ab}, \mathrm{m}$ & $\mathrm{fr}$ & SiL & 0.14 & 8.0 & 100 & 0 & cambic \\
\hline & $\mathrm{Ckc}$ & $115-150$ & 10YR 6/6 & $\mathrm{ab}, \mathrm{c}$ & $\mathrm{fr}$ & SiL & 0.11 & 8.3 & 100 & 16.0 & calcic \\
\hline \multirow[t]{5}{*}{ PL2 } & Ap & $0-35$ & $5 Y 2 / 1$ & $\mathrm{gr} / \mathrm{sb}, \mathrm{m}$ & $\mathrm{fr}$ & SiL & 2.16 & 7.9 & 100 & 2.5 & chernic \\
\hline & Ahk & $35-55$ & $5 Y 2 / 1$ & gr, m & $\mathrm{fr}$ & SiL & 1.64 & 8.1 & 100 & 5.0 & chernic \\
\hline & $\mathrm{ABkl}$ & $55-75$ & $5 \mathrm{Y} 3 / 2$ & $\mathrm{sb} / \mathrm{ab}, \mathrm{m}$ & $\mathrm{fr}$ & SiL & 0.28 & 8.2 & 100 & 19.6 & mollic, calcic \\
\hline & $\mathrm{Ckcl}$ & $75-105$ & $\begin{array}{l}\text { 10Y 6/1 + } \\
10 \mathrm{YR} \mathrm{6/6}\end{array}$ & $\mathrm{ab}, \mathrm{m}$ & fi & SiL & 0.03 & 8.4 & 100 & 15.8 & calcic, gleyic \\
\hline & $2 \mathrm{Ckr}$ & $105-150$ & $10 \mathrm{Y} 6 / 1$ & $\mathrm{mp}$ & $\mathrm{fr}$ & $\mathrm{SL}$ & 0.02 & 8.5 & 100 & 2.1 & gleyic \\
\hline \multirow[t]{2}{*}{ PL3 } & Ap & $0-30$ & $2.5 \mathrm{Y} 3 / 2$ & $\mathrm{sb}, \mathrm{f}$ & $\mathrm{fr}$ & $\mathrm{L}$ & 1.81 & 8.3 & 100 & 15.8 & chernic \\
\hline & $\mathrm{Ckg}$ & $30-80$ & $\begin{array}{l}5 \mathrm{Y} 5 / 3+10 \mathrm{YR} \\
4 / 4\end{array}$ & $\mathrm{mp}$ & $\mathrm{fr}$ & $\mathrm{L}$ & 0.31 & 8.5 & 100 & 15.7 & calcic, stagnic \\
\hline \multirow[t]{3}{*}{ PL4 } & Ap & $0-32$ & 10 YR $2 / 3$ & $\mathrm{sb}, \mathrm{f}$ & $\mathrm{fr}$ & SL & 1.24 & 7.0 & 81 & 2.0 & mollic \\
\hline & $\mathrm{Ab}$ & $32-75$ & 7.5YR 2/1 & gr, m & $\mathrm{fr}$ & $\mathrm{SL}$ & 1.25 & 7.3 & 83 & 2.0 & chernic \\
\hline & $\mathrm{Ckr}$ & $75-100$ & $10 \mathrm{Y} 7 / 2$ & $\mathrm{mp}$ & $\mathrm{fr}$ & SL & - & 8.5 & 100 & 9.2 & $\begin{array}{l}\text { gleyic, } \\
\text { protocalcic }\end{array}$ \\
\hline \multirow[t]{5}{*}{ SK1 } & Ap & $0-25$ & $10 \mathrm{YR} 2 / 2$ & gr, sb & $\mathrm{fr}$ & $\mathrm{SiCL}$ & 1.9 & 7.1 & nd & $<0.1$ & chernic \\
\hline & $\mathrm{Ah}$ & $25-45$ & $10 \mathrm{YR} 2 / 2$ & gr & $\mathrm{fr}$ & $\mathrm{SiCL}$ & 1.4 & 7.3 & nd & $<0.1$ & chernic \\
\hline & $\mathrm{A} 2$ & $45-65$ & 10 YR $3 / 3$ & gr & $\mathrm{fr}$ & $\mathrm{SiCL}$ & nd & nd & nd & nd & mollic \\
\hline & $\mathrm{ACk}$ & $65-95$ & $\begin{array}{l}10 \text { YR } 5 / 4 \\
+3.5 / 3 \\
\end{array}$ & $\mathrm{ab}$ & $\mathrm{fr}$ & $\mathrm{SiC}$ & 0.90 & 7.6 & nd & 15.6 & - \\
\hline & $\mathrm{Ck}$ & 95-(110) & 10YR $6.5 / 6$ & $\mathrm{sb}, \mathrm{mp}$ & $\mathrm{fi}$ & $\mathrm{SiCL}$ & 0.20 & 7.6 & nd & 32.2 & calcic \\
\hline \multirow[t]{8}{*}{ SK2 } & Oi & $3-2$ & - & - & - & nd & 46.4 & 5.5 & nd & nd & - \\
\hline & $\mathrm{Oe}$ & $2-0$ & - & - & - & nd & 24.1 & 6.3 & nd & nd & - \\
\hline & $\mathrm{Ah}$ & $0-10$ & 10 YR $3 / 3$ & gr & $\mathrm{fr}$ & SiL & 2.10 & 4.6 & nd & 0 & - \\
\hline & $\mathrm{ABw}$ & $10-30$ & 7.5YR 4/4 & $\mathrm{sb}$ & $\mathrm{fr}$ & $\mathrm{SiL}$ & 1.11 & 5.1 & nd & 0 & - \\
\hline & Bt1 & $30-60$ & 7.5 YR $3 / 4$ & $\mathrm{ab}$ & $\mathrm{fr}$ & $\mathrm{L}$ & nd & 5.7 & nd & 0 & argic \\
\hline & Bt2 & $60-90$ & 10YR 5/6 & $a b, s b$ & fr & $\mathrm{L}$ & nd & 5.2 & nd & 0 & argic \\
\hline & CBtk & $90-105$ & 10YR 6/6 & $\mathrm{ab}, \mathrm{sb}$ & fi & SiL & nd & 7.0 & nd & 4.2 & - \\
\hline & $\mathrm{Ck}$ & $105-(130)$ & $2.5 \mathrm{Y} 6 / 4$ & $\mathrm{ab}, \mathrm{sb}$ & fi & SiL & nd & 7.6 & nd & 26.9 & calcic \\
\hline \multirow[t]{3}{*}{ HU1 } & $\mathrm{Ah}$ & $0-55$ & $10 \mathrm{YR} 3 / 2$ & $\mathrm{gr} / \mathrm{sb}, \mathrm{f}$ & $\mathrm{fr}$ & $\mathrm{SiL}$ & 2.60 & 6.9 & nd & 3.1 & chernic \\
\hline & $\mathrm{AB}$ & $55-83$ & $10 \mathrm{YR} 4 / 2$ & $\mathrm{sb}, \mathrm{f} / \mathrm{m}$ & $\mathrm{fr}$ & $\mathrm{SiL}$ & 1.20 & 8.1 & nd & 5.0 & cambic \\
\hline & $\mathrm{Ck}$ & $83-110$ & $2.5 \mathrm{Y} 4 / 4$ & $\mathrm{sb}, \mathrm{f} / \mathrm{m}$ & $\mathrm{fr}$ & $\mathrm{SiL}$ & 0.50 & 8.3 & nd & 15.5 & calcic \\
\hline \multirow[t]{6}{*}{ HU2 } & Ap & $0-20$ & 10YR 3/2 & $\mathrm{sb}, \mathrm{f} / \mathrm{vf}$ & vfr & SiL & 1.43 & 6.8 & nd & 0 & chernic \\
\hline & Ap2 & $20-40$ & 10 YR $3 / 2$ & $\mathrm{sb}, \mathrm{f} / \mathrm{vf}$ & vfr & SiL & 1.53 & 6.8 & nd & 0 & chernic \\
\hline & $\mathrm{A}$ & $40-55$ & 10 YR $3 / 2$ & $\mathrm{gr} / \mathrm{sb}, \mathrm{f}$ & $\mathrm{fr}$ & SiL & 0.66 & 7.3 & nd & 29.8 & mollic \\
\hline & $\mathrm{AB}$ & $55-80$ & $10 \mathrm{YR} 4 / 3$ & $\mathrm{gr} / \mathrm{sb}, \mathrm{vf}$ & $\mathrm{fr}$ & SiL & 0.94 & 7.3 & nd & 20.5 & cambic, calcic \\
\hline & $\mathrm{BCk}$ & $80-120$ & $2.5 Y 5 / 4$ & $\mathrm{ab}, \mathrm{f} / \mathrm{m}$ & $\mathrm{fr}$ & SiL & 0.38 & 7.4 & nd & 26.6 & cambic, calcic \\
\hline & $\mathrm{Ck}$ & $120-160$ & $2.5 \mathrm{Y} 5 / 4$ & $a b, f / m$ & $\mathrm{fr}$ & SiL & 0.27 & 8.1 & nd & 31.6 & calcic \\
\hline \multirow[t]{5}{*}{ HU3 } & Ap & $0-28$ & 10YR 2/1 & $\mathrm{gr} / \mathrm{sb}, \mathrm{f} / \mathrm{m}$ & vfr & $\mathrm{CL}$ & 1.60 & 7.0 & nd & 1.1 & chernic \\
\hline & Ah1 & $28-50$ & 10YR 2/1 & $\mathrm{gr} / \mathrm{sb}, \mathrm{f} / \mathrm{m}$ & vfr & $\mathrm{CL}$ & 1.64 & 7.3 & nd & 1.5 & chernic \\
\hline & Ah2 & $50-80$ & 10 YR $3 / 2$ & $\mathrm{sb}, \mathrm{m}$ & $\mathrm{fr}$ & $\mathrm{CL}$ & 1.30 & 8.2 & nd & 1.8 & mollic \\
\hline & $\mathrm{ACk}$ & $80-110$ & $2.5 Y 5 / 3$ & $\mathrm{sb}, \mathrm{m}$ & $\mathrm{fr}$ & SiL & 0.60 & 8.4 & nd & 26.9 & calcic \\
\hline & $\mathrm{Ck}$ & $110-135$ & $2.5 \mathrm{Y} 6 / 4$ & $\mathrm{sb}, \mathrm{m}$ & $\mathrm{fr}$ & SiL & nd & 8.6 & nd & 28.1 & calcic \\
\hline
\end{tabular}


Table 2. continued

\begin{tabular}{|c|c|c|c|c|c|c|c|c|c|c|c|}
\hline \multirow{2}{*}{$\begin{array}{l}\text { Profile } \\
\text { ID } \\
\end{array}$} & \multirow{2}{*}{ Horizon } & \multirow{2}{*}{$\frac{\text { Depth }}{\mathrm{cm}}$} & \multirow{2}{*}{$\begin{array}{l}\text { Colour } \\
\text { (moist) }\end{array}$} & \multirow[t]{2}{*}{ Structure } & \multirow{2}{*}{$\begin{array}{l}\text { Consi- } \\
\text { stence }\end{array}$} & \multirow{2}{*}{$\begin{array}{l}\text { Texture } \\
\text { class }\end{array}$} & \multirow{2}{*}{$\begin{array}{l}\text { TOC } \\
\%\end{array}$} & \multirow[t]{2}{*}{$\mathrm{pHw}$} & \multirow{2}{*}{$\frac{\mathrm{BS}}{\%}$} & \multirow[t]{2}{*}{$\mathrm{CaCO}_{3}$} & \multirow[t]{2}{*}{ Diagnostics } \\
\hline & & & & & & & & & & & \\
\hline \multirow[t]{3}{*}{ HU4 } & $\mathrm{Ap}$ & $0-35$ & $2.5 \mathrm{Y} 3 / 2$ & $\mathrm{gr} / \mathrm{sb}, \mathrm{m}$ & vfr & $\mathrm{CL}$ & 1.20 & 8.0 & nd & 7.6 & chernic \\
\hline & $\mathrm{BCk}$ & $35-60$ & $2.5 Y 5 / 3$ & $\mathrm{sb}, \mathrm{m} / \mathrm{c}$ & vfr & $\mathrm{L}$ & nd & 8.6 & nd & 13.4 & protocalcic \\
\hline & $\mathrm{Ck}$ & $60-80$ & $2.5 \mathrm{Y} 6 / 4$ & $\mathrm{sb}, \mathrm{m} / \mathrm{c}$ & fr & SL & nd & 8.7 & nd & 22.2 & calcic \\
\hline \multirow[t]{6}{*}{ HU5 } & Ap & $0-20$ & 10YR 2/1 & $\mathrm{gr}, \mathrm{f}$ & $\mathrm{fr}$ & $\mathrm{L}$ & 1.70 & 6.9 & nd & 0 & chernic \\
\hline & $\mathrm{Ah}$ & $20-35$ & 10YR 2/1 & $\mathrm{pl} / \mathrm{sb}, \mathrm{f} / \mathrm{m}$ & $\mathrm{fr}$ & $\mathrm{CL}$ & 1.50 & 7.6 & nd & 0 & chernic \\
\hline & $2 \mathrm{ABt}$ & $35-55$ & 10YR 2/1 & $\mathrm{pr}, \mathrm{f} / \mathrm{m}$ & $\mathrm{fr}$ & $\mathrm{C}$ & 1.10 & 7.7 & nd & 0 & mollic \\
\hline & $2 \mathrm{Btg}$ & $55-70$ & $2.5 Y 3 / 1$ & $\mathrm{pr}, \mathrm{f} / \mathrm{m}$ & $\mathrm{fr}$ & $\mathrm{C}$ & 0.70 & 8.1 & nd & 1.1 & mollic \\
\hline & $2 \mathrm{BCk}$ & $70-110$ & $2.5 \mathrm{Y} 3 / 2$ & $\mathrm{sb}, \mathrm{m}$ & $\mathrm{fr}$ & $\mathrm{C}$ & 0.30 & 8.6 & nd & 17.4 & calcic \\
\hline & 2BCk2 & $110-130$ & $2.5 \mathrm{Y} 4 / 3$ & $\mathrm{sb}, \mathrm{m}$ & fi & $\mathrm{C}$ & 0.20 & 8.8 & nd & 16.1 & calcic \\
\hline \multirow[t]{5}{*}{ HU6 } & Ap & $0-20$ & $10 \mathrm{YR} 2 / 2$ & gr, f & vfr & $\mathrm{SiCL}$ & 2.90 & 7.4 & 100 & 1.9 & chernic \\
\hline & $\mathrm{Ah}$ & $20-50$ & $10 \mathrm{YR} 2 / 1$ & $\mathrm{gr} / \mathrm{sb}, \mathrm{f} / \mathrm{m}$ & $\mathrm{fr}$ & $\mathrm{SiCL}$ & 2.30 & 7.8 & 100 & 3.9 & chernic \\
\hline & $\underline{B k}$ & 50-95 & $10 \mathrm{YR} 4 / 2$ & $\mathrm{sb}, \mathrm{f}$ & $\mathrm{fr}$ & $\mathrm{SiCL}$ & 0.90 & 8.4 & 100 & 17.6 & calcic \\
\hline & $\mathrm{BCk}$ & $95-110$ & $2.5 \mathrm{Y} 5 / 4$ & $\mathrm{ma}$ & $\mathrm{fr}$ & CL & 0.20 & 9.1 & 100 & 15.5 & calcic \\
\hline & $\mathrm{Ck}$ & $110+$ & 2.5 Y $6 / 4$ & $\mathrm{ma}$ & fi & $\mathrm{C}$ & 0.18 & 9.3 & 100 & 12.7 & $\begin{array}{l}\text { protocalcic, } \\
\text { protosalic }\end{array}$ \\
\hline
\end{tabular}

Explanation: texture class: C - clay, CL - clay loam, L - loam, SiCL - silty clay loam, SiL - silt loam, SL - sandy loam; structure type: gr - granular, $\mathrm{sb}$ - blocky subangular, ab - blocky angular, pr - prismatic, pl - platy, ma - massive; aggregate size: $\mathrm{f}$ - fine, $\mathrm{m}$ - medium, $\mathrm{c}$ - coarse; consistence: $\mathrm{vfr}$ - very friable, $\mathrm{fr}$ - friable, fi - firm; $\mathrm{TOC}$ - total organic carbon, $\mathrm{pHw}-\mathrm{pH}$ in distilled water; $\mathrm{BS}$ - base saturation; nd - not determined.

Such transformation of Chernozems into Luvisols took place mainly in the moister, peripheral parts of the Danube hilly lands. The intensity of soil forming processes varied across hilly lands from warmer and drier parts towards the cooler, moister and more elevated peripheral foot slopes (in this case foots of the Little Carpathians Mts.). That resulted in the formation of various soils with chernic/mollic horizons combined with argic or cambic horizons, known as soil piedmont zonality (Bedrna 1966; Fulajtár et al. 2016). In a drier central parts of the hilly land, the mollic/chernic horizons were preserved, but intense farming followed by surface erosion led in many cases to significant degradation (reduction in thickness) of the topsoil humus horizons, as reported from Czech Republic (Zádorová et al. 2013).

\section{Hungary}

Chernozems or chernozem-like soils, according to the genesis-based current Hungarian soil classification system (Földvári 1966; Stefanovits 1992; Michéli and Krasilnikov 2009), cover 22.4\% of Hungary, being one of the most important soil types in terms of agricultural productivity. Considered as zonal soils of the Hungarian lowland steppe and forest steppe vegetation, chernozems are widespread on flat and slightly sloping hilly areas and foothills, where the limiting soil forming factors, such as shallow consolidated parent material, shallow (saline) groundwater and light (sandy) or heavy (shrink-swell clays) textures are absent (Várallyay 2015). Correlation of the principally genesis-based Hungarian soil taxa with WRB units, and their mutual conversion are often challenging (Michéli et al. 2006; Pásztor et al. 2014). The approximate equivalents of the Hungarian chernozemic soils in the WRB classification are Phaeozems, Kastanozems and Chernozems (Michéli et al. 2014), or in some cases they are interpreted as Mollic Vertisols and Mollic Gleysols. Chernozemic soils, in many places, have been cultivated since the Neolithic age (ca. 8,000 years BP), and have been affected by profound anthropogenic, climatic and land use influences over the past few thousand years (Farsang et al. 2015).

Driving factors of the differentiation of various chernozem subtypes are vegetation, texture and moisture regime and dynamics, which may result in either gleyic (or stagnic) features or saline and alkaline properties (Michéli et al. 2019). Soil types transitional to "forest brown soils" (presumably correlated with Luvisols) are typical on elevated, partially forested foothill areas (in Hungary called leached and eluviated chernozems, and chernozems with "forest remnants", fig. 2c, HU1) (Láng et al. 2013). They are distinguished from other chernozems by their relatively low $\mathrm{pH}$ in the topsoil, high, but unstable organic carbon contents and, partially, by the presence of clay and humus cutans (Michéli et al. 2019). Archetypical chernozems cover the flat, loess covered plains made up 


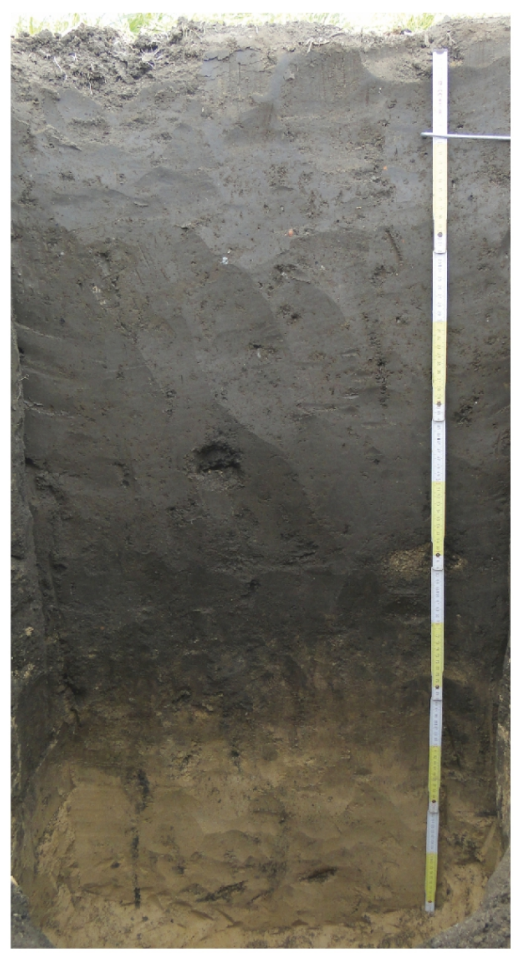

PL1: Czarnoziem wyługowany WRB2015: Haplic Chernozem (Aric, Pachic, Siltic, Bathycalcic)

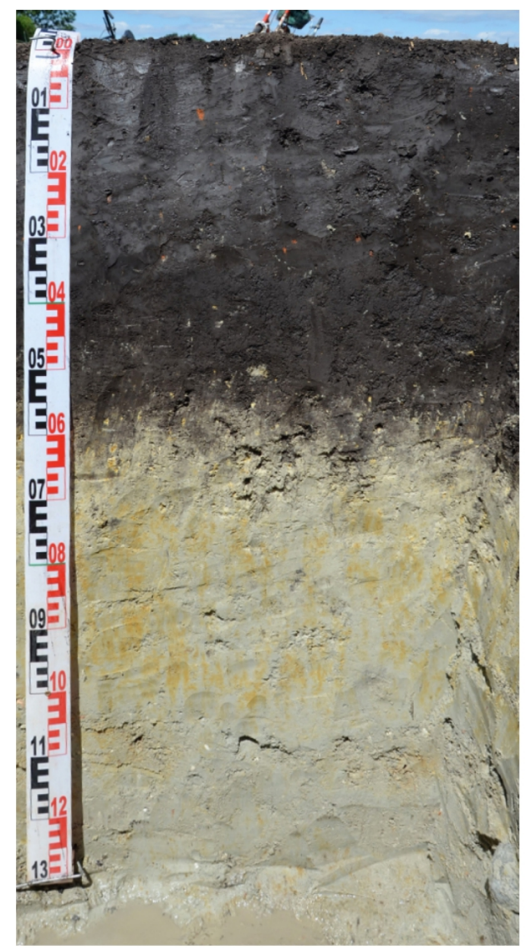

PL2: Czarna ziemia typowa WRB2015: Endogleyic Chernozem (Aric. Pachic, Siltic, Bathyloamic, Bathyraptic)

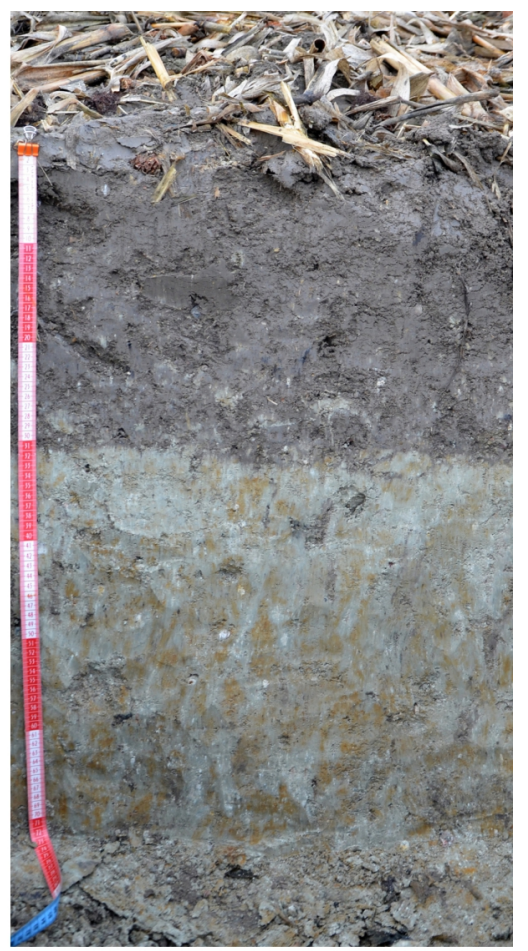

PL3: Czarna ziemia kalcikowa WRB2015: Calcic Chernozem (Aric, Loamic, Katostagnic)

FIGURE 2a. Morphology and classification (local and WRB classifications) of soil profiles

of carbonate rich unconsolidated silty materials where even the deeper parts of the soil profile are unaffected by groundwater. Calcic horizons, often distinctive for chernozems, are frequently characterized by pseudomycelia, considered as the evidence of vertical carbonate fluctuation within the profile (fig. 2c, profiles HU2 and HU3). Deep mixing of the organic materials due to high biological activity is sometimes observed in the form of earthworm channel infillings (HU2) or in form of burrows of small soil-dwelling mammals, i.e. krotovinas (fig. 2c-d, profiles HU3 and HU6). The stability of organic matter in these soils produces high organic carbon contents even after several millennia of cultivation. Slightly undulating landforms may also lead to heavy erosion during the prolonged periods of cultivation. Hence the original chernic horizon, having been continuously mixed with the subsoil, has been thinning and its lower boundary is often abrupt (HU4), indicating a ploughed topsoil as a common anthropogenic feature of these soils. As a consequence of further erosion, the chernic horizon loses its favourable granular structure and its organic carbon content decreases. According to requirements of the present version of WRB, the eroded soil with medium or even coarser subangular or angular blocky aggregates typically classifies as Kastanozem, or as a result of very heavy erosion, it may be considered Calcisol (IUSS Working Group WRB 2015). This process is extensive on the rolling hills of the loess plains and plateaus and leads to the exclusion of many of chernozem-like soils (based on Hungarian classification) from the Chernozems defined by WRB (Novák et al. 2018a).

The "meadow chernozems" located on low-lying plains and especially floodplains with seasonally shallow groundwater levels are typically characterized by gleyic features (Fuchs et al. 2011). On the plains covered by clayey sediments, gleyic and stagnic features are often paralelly present in the profile. However, the very dark (blackish) colour of the humus rich horizon may cover these features creating a blurry and hardly recognizable appearance (Farkas et al. 2009; Dóka 2013). Due to the river regulation and drainage of extensive areas in the 18th and 19th centuries, the gleyic and even stagnic features (except of relictistagnic/relictigleyic properties) regularly do not meet the corresponding diagnostic criteria (Fuchs et al. 2011). Some of the lowland sediments in Hungary are clay-rich, which has a significant impact on the structure of these soils. The structure of soil HU5 in its uppermost two horizons fulfils the criteria of chernic, but in many cases clay-rich chernozemic 


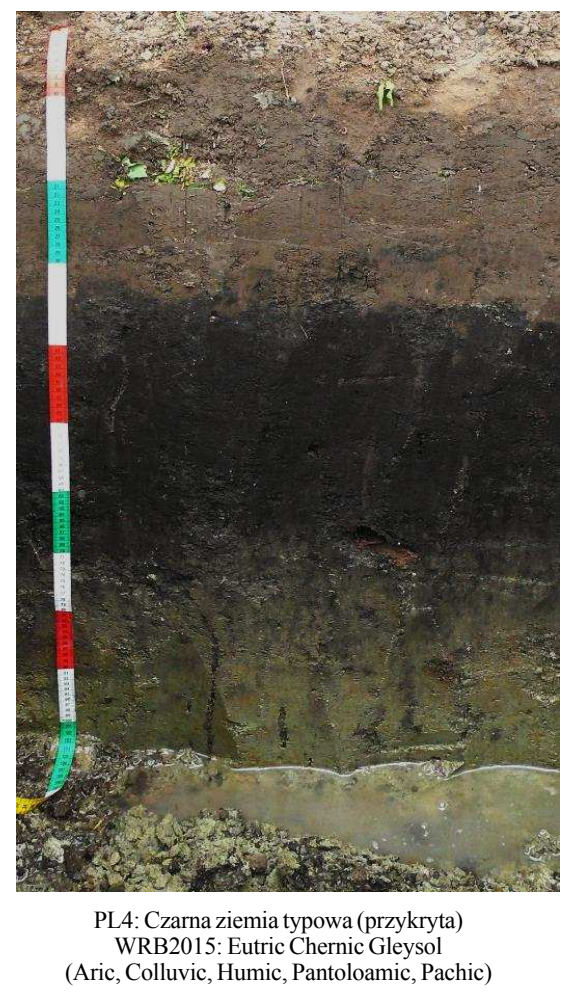

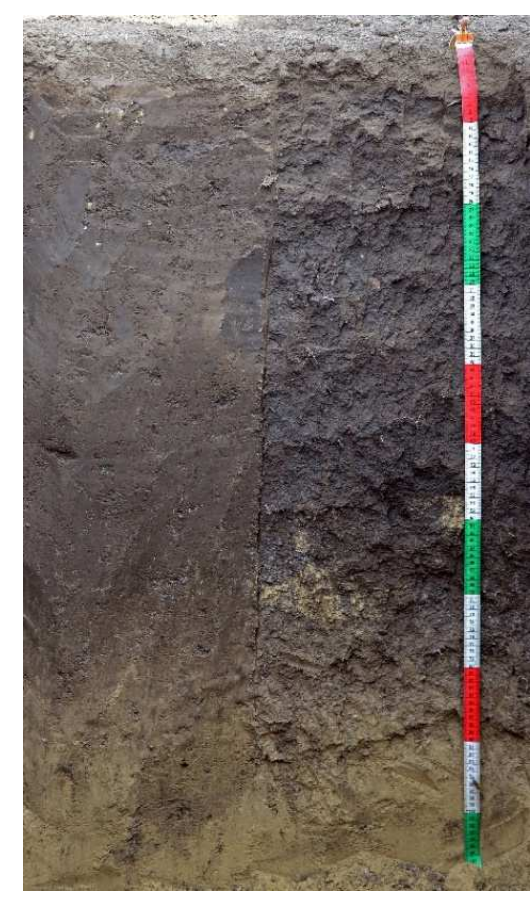

SK1: Černozem kultizemná karbonátová WRB2015: Calcic Chernozem (Loamic, Aric, Pachic)

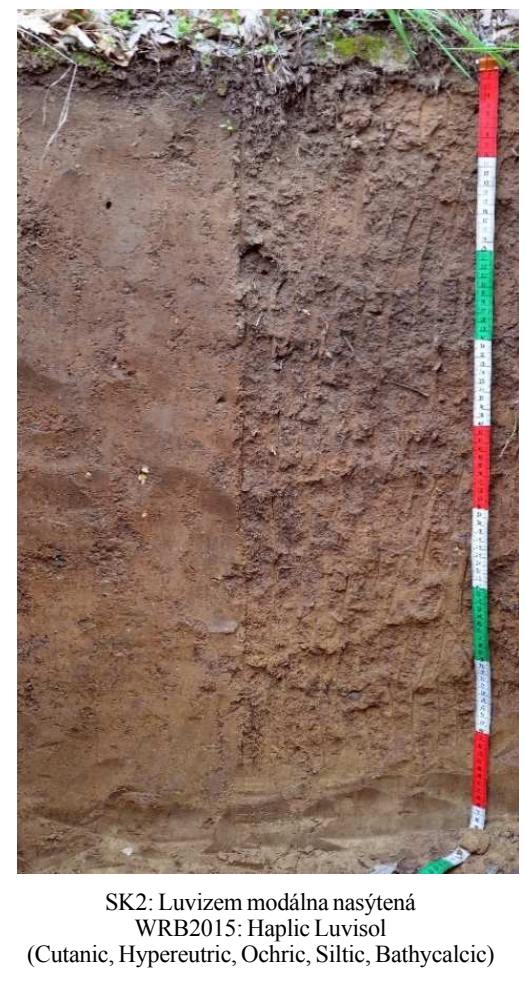

FIGURE 2b. Morphology and classification (local and WRB classifications) of soil profiles (continued)

soils of the eastern part of the Great Hungarian Plain (GHP) have significantly coarser, subangular or prismatic structure (Novák et al. 2018a). They may also have anthropogenically compacted, degraded structure due to machinery ploughing (Farsang et al. 2015). Therefore, they must be classified as Kastanozems (according to present version of WRB). Another way of transformation of chernozemic soils is related to intensive cultivation, e.g. gardening (Novák et al. 2018b). The development of a thick (more than 50 $\mathrm{cm}$ ) hortic or anthric features results in the transformation of Chernozem into Anthrosol.

Moreover, on extensive areas of the GHP the high groundwater salinity generates solonetzic or saline features in the deeper soil horizons (profile HU6). These soils appear as small inclusions within large areas of salt affected soils. Aside from fulfilling the criteria for Chernozems, they are often designated with either Bathysalic or Bathysodic qualifiers, and thus represent transitional forms to Solonetzs and Solonchaks groups (Novák and Tóth 2016).

\section{Soil variability identified by WRB and local soil classifications}

Brief overview of chernozemic soils features in three Central European countries (Poland, Slovakia and Hungary) has shown that these soils occur in various variants, which reflect the influences of climate, topography, vegetation, but also land use and intensity of farming.

In all three countries, soils considered "typical chernozems" have been identified. All these soil have common morphological and physicochemical features expected in chernozems, i.e. are developed from loess or loess-like materials, have thick, humus-rich and blackish topsoil horizon and also have accumulation of secondary carbonates in the profile (tab. 2, profiles PL1, SK1, HU2-HU3). All these soils fulfil criteria of Haplic/Calcic Chernozems (IUSS Working Group WRB 2015), considered the most typical forms of Chernozems in a WRB (Driessen et al. 2001). Although only few soil profiles are involved in this comparison, the properties of chernozems clearly change from south to north. The organic carbon content is lower in the upper $50 \mathrm{~cm}$ layer of chernozems in SW Poland (0.6-1.2\%) compared to soils in Slovakia (1.4-1.9\%) and Hungary (1.2-2.6\%). Significant accumulation of secondary carbonates $\left(>15 \%\right.$ of $\left.\mathrm{CaCO}_{3}\right)$ starts in $\mathrm{SW}$ Poland commonly deeper than $100 \mathrm{~cm}$, whereas in Slovakia and in Hungary at $40-80 \mathrm{~cm}$ (tab. 2). These single examples correspond well with numerous available characteristics of chernozems in those countries (Hraško 1966; Turski 1985; Skalský et al. 


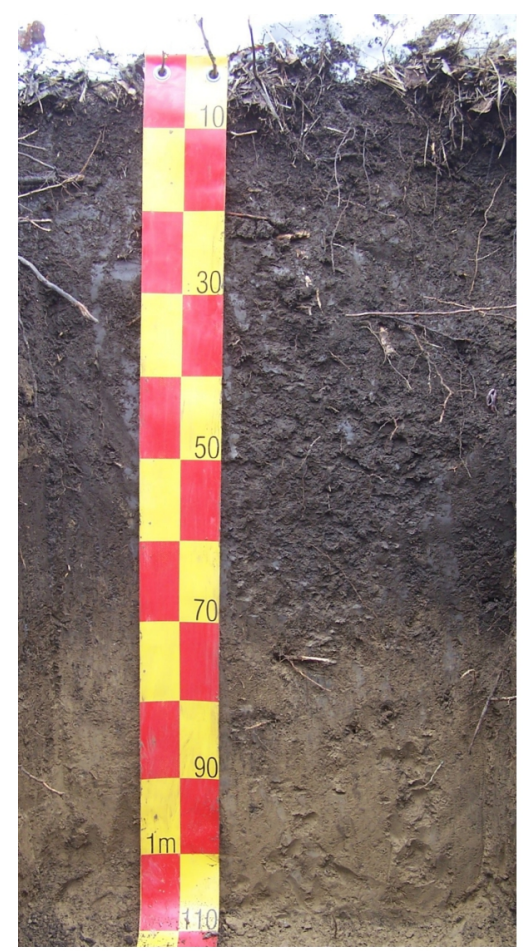

HU1: Erdömaradványos csernozjom WRB2015: Calcic Chernozem (Pachic, Siltic)

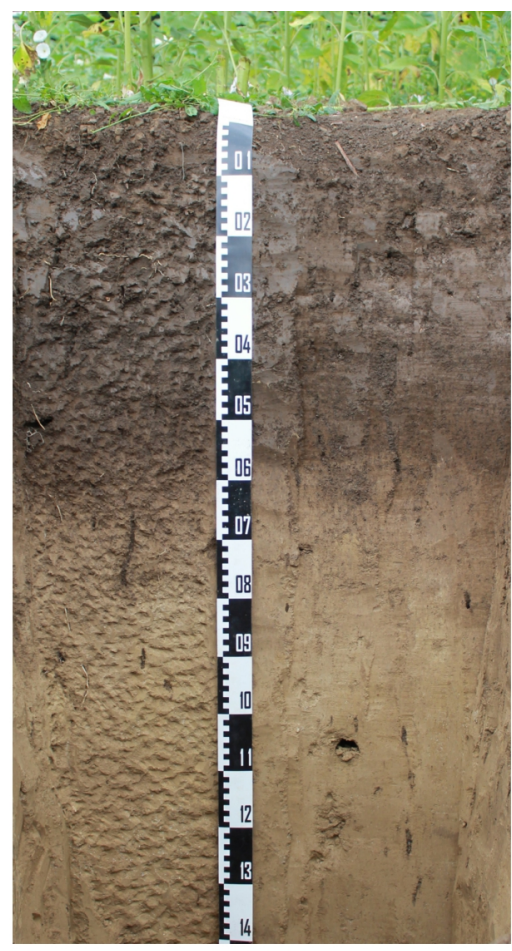

HU2: Mészlepedékes csernozjom WRB2015: Calcic Chernozem (Aric, Pachic, Siltic)

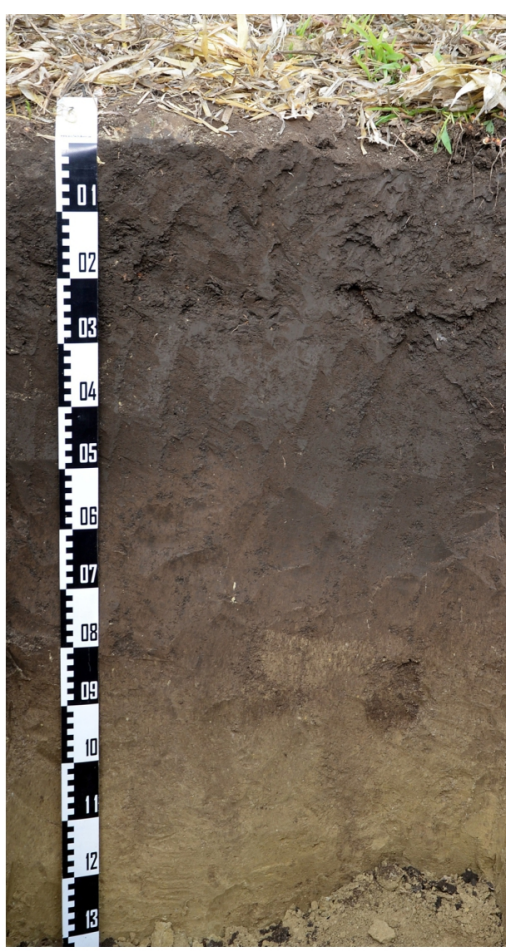

HU3: Mészlepedékes csernozjom WRB2015: Calcic Chernozem (Aric, Pachic, Anoloamic, Endosiltic, Bathystagnic)

FIGURE 2c. Morphology and classification (local and WRB classifications) of soil profiles (continued)

2009; Novák et al. 2014, 2018a; Šimanský et al. 2016; Vyslou•ilová et al. 2016; Jonczak et al. 2017; Łabaz et al. 2018, 2019b) and support a common opinion, that chernozems existing under more continental climate are more enriched in humus and less leached compared to chernozems existing under more humid climate; the latter therefore considered a "degraded" variety (Borowiec 1968; Eckmeier et al. 2007; Kabała 2019). The differences between chernozems along a transect Hungary - Slovakia - Poland are similar, to some extent, to zonal differentiation of these soils from more southern steppe to more northern foreststeppe zones in European Russia (Afanasyeva 1966; Khitrov et al. 2019) or in Ukraine (Pozniak and Havrysh 2019).

The above mentioned climate-driven differentiation is reflected in many other soil properties. Salt accumulation and protosalic conditions (profile HU6) are present only in the chernozems in Hungary (the most continental and the driest of the countries under comparison). Whereas, many chernozemic soils located in Poland, the most humid of the countries under comparison, are featured by the presence of strongly developed redoximorphic features (fig. 2a). Due to prolonged seasonal or permanent reducing conditions, commonly existing in a middle/upper part of soil profile, that disturb rapid mineralization and favour accumulation of humified organic matter, the topsoil horizons of these hydromorphic soils are more rich in organic carbon compared to "typical" (well drained) chernozems and have nearly black colour of topsoil horizon (PL2, PL4). Therefore, the soils are called black earths - czarne ziemie in Poland and čiernice in Slovakia (fig. 2a-b). Czarne ziemie/čiernice typically have mollic (or chernic) horizon, respectively to their name, and the gleyic or stagnic properties directly below mollic horizon, respectively to their hydromorphic identity (tab. 1). If the secondary carbonates are present forming the calcic horizon or protocalcic properties, the soil may meet requirements for Gleyic/Stagnic Chernozems (fig. 2a, profiles PL2 and PL3). If carbonates are leached more deeply (more than $50 \mathrm{~cm}$ below the bottom of mollic) or the topsoil horizon does not fulfil criteria for chernic horizon, the soils are classified as Gleyic/Stagnic Phaeozems (Łabaz and Kabała 2014, Łabaz et al. 2019a). In a most "extreme" case, where gleyic properties are present directly below mollic horizon and the reducing condition start below the depth of $40 \mathrm{~cm}$ (even within the mollic/ chernic horizon), the soils must be recognized as Mollic Gleysol (fig. 2b, profile PL4). The above comparison reveals some difference between national clas- 


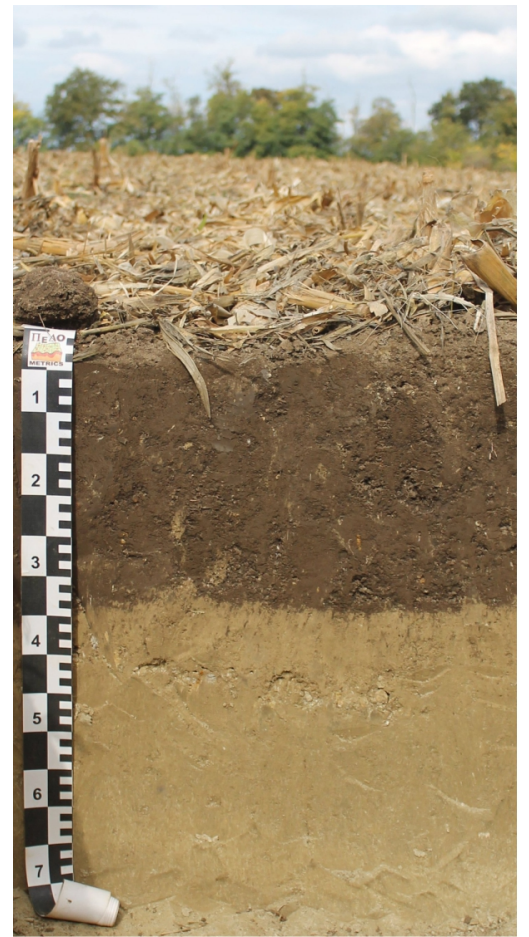

HU4: Mészlepedékes csernozjom WRB2015: Calcic Chernozem (Aric, Pantoloamic)

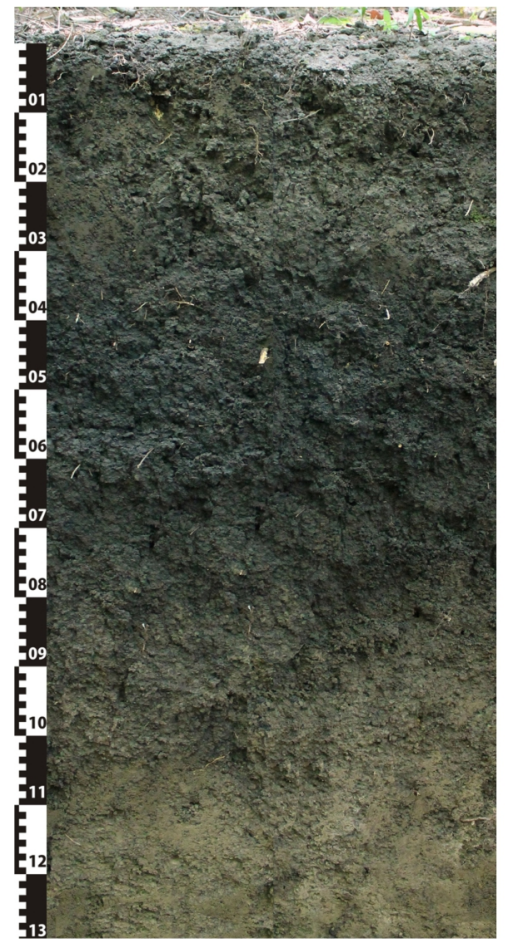

HU5: Réti csernozjom WRB2015: Luvic Calcic Chernozem (Aric, Epiloamic, Clayic, Pachic)

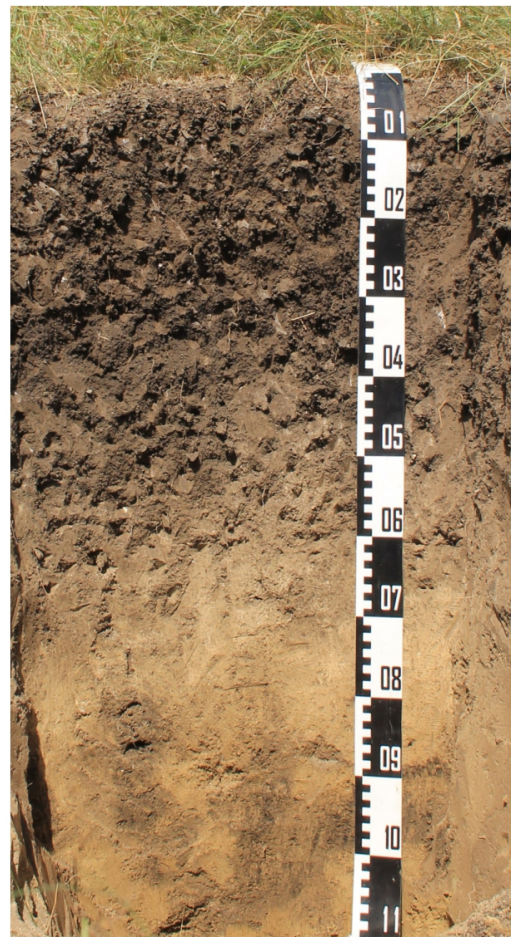

HU6: Mélyben sós alföldi mészlepedékes csernozjom WRB2015: Calcic Chernozem (Loamic, Pachic, Bathyprotosalic)

FIGURE 2d. Morphology and classification (local and WRB classifications) of soil profiles (continued)

sifications and WRB. The czarne ziemie/čiernice are placed among chernozemic soils at the same level with chernozems that highlights the high priority given to hydromorphic features present in the upper and/or middle parts or the soil profile, equal to the presence of mollic/chernic horizons (Societas Pedologica Slovaca 2014; Kabała et al. 2019b). Whereas in the WRB, the redoximorphic features (gleyic/stagnic properties) have secondary importance and are indicated at second/third level (as principal or supplementary qualifiers) in Chernozems/Phaeozems. Alternatively, soils with redoximorphic features present at particularly shallow depth are recognised preferentially as hydromorphic Gleysols or Stagnosols, that makes the presence of mollic/chernic horizons a secondary (accompanying) feature.

The other common, but variably developed feature of chernozemic soils under study is the clay translocation within the profile and the development of illuvial ABt or even Bt horizon. Weak to medium clay (and sometimes of humus) translocation may be hardly recognisable in a profile morphology (fig. 2a, profiles PL1 and HU3, HU5); however, it may be easily detected during the careful structure/texture investigation. The "extreme" stadium of chernozem degradation by leaching, clay eluviation and humus decomposition under forest vegetation, typical for temperate humid climate, resulting in a complete chernozem transformation into Luvisol, displays the profile SL2 (fig. 2b). Various transitional forms between Chernozems/Phaeozems and Luvisols/Retisols have been reported from Central and Eastern Europe (Borowiec 1968; Chendev et al. 2017; Khitrov et al. 2019), but the most spectacular documentation (including the dating) of the processes of chernozem degradation provide the studies in the archaeological sites, in particular on kurgans (Barczi et al. 2006; Alexandrovskiy et al. 2014; Vysloužilová et al. 2014b; Kabała et al. 2019b).

Chernozems in Central Europe may acquire new morphological and physicochemical features under natural influences of more or less humid climate; however, the most serious threat for the presence of these soils is related to intense gardening or farming (Novák et al. 2018b), typically connected with landscape opening and topsoil ploughing, that may result in accelerated sheet erosion. The phenomena, reported from all hilly areas of Central Europe (Turski 1985; Zádorová et al. 2013; Świtoniak 2014; Novák et al. 2016, 2018a; Smetanová et al. 2017), may lead to significant thinning of humus horizon, finally equal to 
the thickness of a plough layer (fig. 2b-d, profiles PL3, HU4). Until the plough layer keeps the criteria for mollic/chernic horizon (including the thickness, colour, humus content and structure), the soil is classified as Chernozem (typically - a Calcic Chernozem). If the admixture of lighter-coloured and humus-free subsoil to the plough layer places the topsoil horizon beyond the criteria for mollic/chernic horizon, the soil is "artificially" shifted to Calcisols (Zádorová et al. 2013), correlated in the national classifications with various types of poorly developed soils, i.e. regosols or pararendzinas (Drewnik and Żyła 2019).

Complementary to eroded soils, which may not fulfil the criteria for chernozems, the colluvial chernozems may develop in the footslope and other low/ concave landscape positions (Zádorová et al. 2013). These "upbuilt" soils fulfil criteria for Chernozems (with supplementary qualifier Colluvic, and typically also Pachic) if the accumulated colluvial material is rich enough in humified organic matter to meet the criteria for mollic/chernic horizon, like in profile PL4 (tab. 2, fig. 2b). This colluvial cover over native soil profile that may significantly thicken the humus horizon (mollic/chernic), is differently recognised in particular national classifications. Only the Polish system (Kabała et al. 2019b) classifies the chernozemic colluvial soils as separate unit at the basic level of soil classification (equal to chernozems), if the thickness of colluvial material reaches $50 \mathrm{~cm}$ and more; whereas the international and other national systems distinguishes colluvial features in chernozemic soils at lower levels of classification (Stefanovits 1992; Němeček et al. 2011; Societas Pedologica Slovaca 2014). In the profile PL4 (fig. 2b) the colluvial cover is too thin $(<50 \mathrm{~cm})$ to become a separate soil type according to the Polish classification and thus it is recognised at variety level only; while according to WRB - the soil gets the supplementary qualifier Colluvic.

\section{CONCLUSIONS}

Chernozemic soils identified after the presence of thick, black or very dark, rich in humus, well-structural and base-saturated topsoil horizon, and the accumulation of secondary carbonates within the soil profile, occur in Central Europe in variable forms, respectively to climate gradients (more Atlantic - more continental), position in the landscape, land use, as well as erosion/accumulation intensity.

The most "typical" chernozems are similarly positioned at a basic level in the national soil classifications in Poland, Slovakia and Hungary, and may be easily correlated with Calcic or Haplic Chernozems, distinguished at highest level in WRB system. "Hydromorphic" chernozemic soils, particularly common in Poland, in some national classifications are placed as separate soil type, paralelly (at the same level) to the "typical" chernozems (e.g. czarne ziemie or čiernice). In WRB these soils may belong to Gleyic/ Stagnic Chernozems/Phaeozems in the case of deeper presence of the redoximorphic features, or to Mollic/ Chernic Gleysols/Stagnosols, in case of very shallow occurrence of reducing conditions and redoximorphic features. The placement of chernozemic soils at various stages of their transformation, in particular featured by base cations leaching, clay translocation or salt/sodium accumulation is similar in the national and WRB classifications. Significant differences between national classifications and WRB were identified in case of soils degraded by erosion or aggraded by accumulation of colluvial materials.

Although WRB classification differs from national classifications in the concepts and priorities of classification, it provides large opportunity to reflect the spatial variability and various stages of transformation/ degradation of chernozemic soils in Central Europe, using a simple, two-three-level system of soil naming.

\section{REFERENCES}

Afanasyeva E.A., 1966. Chernozems of the middle Russian Upland. Nauka, Moscow: 223 pp.

Alexandrovskiy A.L., Sedov S.N., Shishkov V.A., 2014. The development of deep soil processes in ancient kurgans of the North Caucasus. Catena 112: 65-71.

Barczi A., Tóth T.M., Csanádi A., Sümegi P., Czinkota I., 2006. Reconstruction of the paleo-environment and soil evolution of the Csípo-halom kurgan, Hungary. Quaternary International 156: 49-59.

Bedrna Z., 1966. Topografický rad pôd výškovej pásmovitosti na Trnavskej pahorkatine. Náuka o Zemi IV, Pedologica 2, Bratislava.

Bieganowski A., Witkowska-Walczak B., Gliński J., Sokołowska Z., Sławiński C., Brzezińska M., Włodarczyk T., 2013. Database of Polish arable mineral soils: a review. International Agrophysics 27(3): 335-350.

Borowiec J., 1968. The problem of typology and development trends of chernozems occurring in Poland. Roczniki Gleboznawcze - Soil Science Annual 19: 253-260.

Chendev Y.G., Aleksandrovskiy A.L., Khokhlova O.S., Dergacheva M.I., Petin A.N., Golotvin A.N., Uvarkin S.V., 2017. Evolution of forest pedogenesis in the south of the foreststeppe of the Central Russian Upland in the Late Holocene. Eurasian Soil Science 50: 1-13.

Cieśla W., 1965. Problematyka czarnych ziem Niziny Wielkopolskiej ze szczególnym uwzględnieniem Kujaw. Rocz. WSR Poznań 30: 43-53.

Długosz J., Kobierski M., Spychaj-Fabisiak E., 1997. Skład mineralogiczny frakcji ilastej warstwy ornej wybranych czarnych ziem kujawskich. Roczniki Gleboznawcze - Soil Science Annual 48(1/2): 87-93. 
Dóka L., 2013. Moisture regime of chernozem soil at different water supply levels Agrokémia és Talajtan 62(1): 23-36. https://doi.org/10.1556/Agrokem.62.2013.1.2

Drewnik M., Skiba M., Szymański W., Żyła M., 2014. Mineral composition vs. soil forming processes in loess soils-a case study from Kraków (Southern Poland). Catena 119: 166-173.

Drewnik M., Żyła M., 2019. Properties and classification of heavily eroded post-chernozem soils in Proszowice Plateau (Southern Poland). Soil Science Annual 70(3): 225-233.

Driessen P., Deckers J., Spaargaren O., Nachtergaele F., 2001. Lecture notes on the major soils of the world. Food and Agriculture Organization (FAO) Reports, 94, Rome: 334 pp.

Eckmeier E., Gerlach R., Gehrt E., Schmidt M.W.I., 2007. Pedogenesis of Chernozems in central Europe - A review. Geoderma 139: 288-299.

Farkas C., Hernádi H., Makó A., Máté F., 2009. Climate sensitivity of the soil water regime on pseudomyceliar chernozem soils. Agrokémia és Talajtan 58(2): 197-214. https://doi.org/ 10.1556/Agrokem.58.2009.2.3

Farsang A., Szolnoki Z., Barta K., Puskás I., 2015. Proposal for the classification of anthropogenic soils in the framework of the updated Hungarian Soil Classification System. Agrokémia és Talajtan, 64: 299-316. https://doi.org/10.1556/ 0088.2015.64.1.22

Földvári G., 1966. Magyarország genetikus talajtípusainak, altípusainak és változatainak szisztematikus jegyzéke. [In:] A genetikus üzemi talajtérképezés módszerkönyve (Szabolcs I., Editor). Országos Mezőgazdasági Minőségvizsgáló Intézet, Budapest: 165-254.

Fuchs M., Waltner I., Szegi T., Láng V. Michéli E., 2011. Taxonomic distances of soil types in Hungary based on soil-forming processes. Agrokémia és Talajtan, 60(1): 33-44. https:/ /doi.org/10.1556/Agrokem.60.2011.1.4

Fulajtár E., Jenčo M., Saksa M., 2016. Soil erosion mapping with the aid of aerial photographs tested at Pastovce, Ipel'ská pahorkatina. [In:] Interdisciplinary studies of river channels and UAV mapping in the V4 region (Šulc Michalková M., Miřijovský J., Editors). Comenius University, Bratislava: 247-268.

Gerasimova M.I., Khitrov N.B., 2012. Comparison of the results of soil profiles' diagnostics performed in three classification systems. Eurasian soil science 45(12): 1087.

Hraško J., 1966. Černozeme Podunajskej nížiny, problémy ich genézy a klasifikácie. Náuka o Zemi III, Pedologica 1, Bratislava.

International Network of Black Soils, 2019. http://www.fao.org/ global-soil-partnership/intergovernmental-technical-panelsoils/gsoc17-implementation/internationalnetworkblacksoils/ en/

IUSS Working Group WRB, 2015. World Reference Base for Soil Resources 2014, Update 2015. International soil classification system for naming soil and creating legends for soil maps. Food and Agriculture Organization of the United Nations, Rome.

Jonczak J., Šimanský V., Polláková N., 2017. The content and profile distribution of carbon and nitrogen fractions susceptible to acid hydrolysis in Haplic Chernozems and Mollic Fluvisols of western Slovakia. Journal of Elementology 22(4): 1295-1309.
Kabała C., 2019. Chernozem (czarnoziem) - Soil of the year 2019 in Poland. Origin, classification and properties of Chernozems in Poland. Soil Science Annual 70(3): 184-192.

Kabała C., Bekier J., Binczycki T., Bogacz A., Bojko O., Cwielag-Piasecka I., Debicka M., Cuske M., Gałka B., Gersztyn L., Glina B., Jamroz E., Jezierski P., Karczewska A., Kaszubkiewicz J., Kawałko D., Kierczak J., Kocowicz A., Krupski M., Woźniczka P., 2015. Soils of Lower Silesia. Polish Society of Soil Science, Polish Society of Humic Substances, Wrocław.

Kabała C., Charzyński P., Chodorowski J., Drewnik M., Glina B., Greinert A., Hulisz P., Jankowski M., Jonczak J., Łabaz B., Łachacz A., Marzec M., Mendyk Ł., Musiał P., Musielok Ł., Smreczak B., Sowiński P., Świtoniak M., Uzarowicz Ł., Waroszewski J., 2019a. Polish Soil Classification, 6th edition - principles, classification scheme and correlations. Soil Science Annual 70(2): 71-97.

Kabała C., Przybył A., Krupski M., Łabaz B., Waroszewski J., $2019 \mathrm{~b}$. Origin, age and transformation of Chernozems in northern Central Europe - New data from Neolithic earthen barrows in SW Poland. Catena 180: 83-102.

Kabała C., Labaz B., 2018. Relationships between soil pH and base saturation - conclusions for Polish and international soil classifications. Soil Science Annual 69(4): 206-214.

Kalinina O., Krause S.E., Goryachkin S.V., Karavaeva N.A., Lyuri D.I., Giani L., 2011. Self-restoration of post-agrogenic chernozems of Russia: Soil development, carbon stocks, and dynamics of carbon pools. Geoderma 162: 196-206.

Khitrov N., Smirnova M., Lozbenev N., Levchenko E., Gribov V., Kozlov D., Rukhovich D., Kalinina N., Koroleva P., 2019. The soil cover patterns of forest-steppe and steppe zones at the East-European Plain. Soil Science Annual 70(3): 198-210.

Krippel E., 1986. Postglaciálny vývoj vegetácie Slovenska. Veda, Bratislava.

Láng V., Fuchs M., Waltner I., Michéli E., 2013. Soil taxonomic distance, a tool for correlation: As exemplified by the Hungarian Brown Forest Soils and related WRB Reference Soil Groups. Geoderma 192: 269-276. https://doi.org/10.1016/ j.geoderma.2012.07.023

Lorz C., Saile T., 2011. Antropogenic pedogenesis of Chernozems in Germany? - A critical review. Quaternary International 243: 273-279.

Łabaz B., Kabała C., 2014. Origin, properties and classification of black earths in Poland. Soil Science Annual 65(2): 80-90.

Łabaz B., Kabała C., Dudek M., Waroszewski J., 2019a. Morphological diversity of chernozemic soils in south-western Poland. Soil Science Annual 70(3): 211-224.

Łabaz, B., Kabala, C., Waroszewski, J., 2019b. Ambient geochemical baselines for trace elements in Chernozems - approximation of geochemical soil transformation in an agricultural area. Environmental monitoring and assessment 191, 19.

Łabaz B., Musztyfaga E., Waroszewski J., Bogacz A., Jezierski P., Kabala C., 2018. Landscape-related transformation and differentiation of Chernozems - Catenary approach in the Silesian Lowland, SW Poland. Catena, 161: 63-76.

Michéli E., Csorba Á., Szegi T., Dobos E., Fuchs M., 2019. The soil types of the modernized, diagnostic based Hungarian Soil Classification System and their correlation with the World reference base for soil resources. Hungarian Geographical Bulletin 68(2): 109-117. https://doi.org/10.15201/hungeobull.68.2.1 
Michéli E., Fuchs M., Hegymegi P., Stefanovits P., 2006. Classification of the major soils of Hungary and their correlation with the World Reference Base for Soil Resources (WRB). Agrokémia és Talajtan 55(1): 19-28.

Michéli E., Krasilnikov P., 2009. The Hungarian Soil Classification System. [In:] A handbook of soil terminology, correlation and classification (Arnold R., Shoba S., Krasilnikov P., Marti J.J.I., Editors) Earthscan, London: 171-176.

Michéli E., Fuchs M., Láng V., Szegi T., Szabóné Kele G., 2014. Methods for modernizng the elements and structure of the Hungarian Soil Classification System. Agrokémia és Talaj$\tan$ 63(1): 69-78.

Němeček J., Mühlhanselová M., Macků J., Vokoun J., Vavříček D., Novák P., 2011. Czech Taxonomic Classification System of Soils. ČZU, Praha.

Novák T. J., ÁrendásT., Switoniak M., 2018a. Soils of an undulating, cultivated loess plateau in North Mezőföld, Central Hungary. [In:] Soil Sequences Atlas IV (Świtoniak M., Charzyński P., Editors). Nicolaus Copernicus University, Torun: 113-123.

Novák T.J., Mester T., Balla D., Szabó G., 2018b. Culti-sequence of village garden soils ont he Great Hungarian Plain. [In:] Soil Sequences Atlas II (Świtoniak M., Charzyński P., Editors). Polish Society of Soil Science, Torun, Poland: 248 pp.

Novák T.J., Incze J., Spohn M., Glina B., Giani L., 2014. Soil and vegetation transformation in abandoned vineyards of the Tokaj Nagy-Hill, Hungary. Catena 123: 88-98.

Novák T.J., Tóth C.A., 2016. Development of erosional microforms and soils on semi-natural and anthropogenic influenced solonetzic grasslands. Geomorphology 254: 121-129.

Pásztor L., Dobos E., Szatmári G., Laborczi A., Takács K., Bakacsi Z., Szabó J., 2014. Application of legacy soil data in digital soil mapping for elaboration of novel, countrywide maps of soil conditions. Agrokémia és Talajtan 63(1): 79-88.

Pozniak S.P., Havrysh N.S., 2019. Soils in the memory of world nations. Polish Journal of Soil Science 52(1): 1-13.

Šály R., Bedrna Z., Bublinec E., Čurlík J., Fulajtár E., Gregor J., Sobocká J., 2000. Morphogenetic classification system of soils in Slovakia. VÚPOP.

Šimanský V., Polláková N., Jonczak J., Jankowski M., 2016. Which soil tillage is better in terms of the soil organic matter and soil structure changes? Journal of Central European Agriculture 17(2): 391-401.

Skalský R., Fulajtár E., Šurina B., 2009. Correlation of chernozems classification in WRB and national Slovak soil classification system. Agrohimia i gruntoznavstvo 69: 87-93.

Smetanová A., Verstraeten G., Notebaert B., Dotterweich M., Létal A., 2017. Landform transformation and long-term sediment budget for a Chernozem-dominated lowland agricultural catchment. Catena 157: 24-34.

Societas Pedologica Slovaca, 2014. Morfogenetický klasifikačný systém pôd Slovenska. Bazálna referenčná taxonómia. Druhé upravené vydanie. Bratislava: NPPC - VÚPOP, Bratislava: $96 \mathrm{pp}$.
Soil Database, 2019: http://soils.umk.pl/database/

Soil Survey Staff, 2014. Keys to Soil Taxonomy, 12th ed. USDANatural Resources Conservation Service, Washington, DC: 633 pp.

Stefanovits P., 1992. Talajtan (3. kiadás) Mezőgazda Kiadó, Budapest: 379 pp.

Świtoniak M., 2014. Use of soil profile truncation to estimate influence of accelerated erosion on soil cover transformation in young morainic landscapes, North-Eastern Poland. Catena 116: $173-184$.

Świtoniak M., Kabała C., Karklins A., Charzyński P., Hulisz P., Mendyk Ł., Michalski A., Novak T., Penizek V., Reintnam E., Repe B., Saksa M., Vaisvalavicius R., Waroszewski J., 2018. Guidelines for Soil Description and Classification Central and Eastern European Students' Version. Nikolaus Copernicus University, Toruń, Poland.

Tóth G., Jones A., Montanarella L., 2013. The LUCAS topsoil database and derived information on the regional variability of cropland topsoil properties in the European Union. Environmental monitoring and assessment 185(9): 7409-7425.

Turski R., 1985. Genesis and properties of Chernozems of the West-Volhynian and Lublin Uplands. Roczniki Nauk Rolniczych series D, 202: 1-83.

Várallyay G., 2015. Soils, as the most important natural resources in Hungary (potentialities and constraints) - A review. Agrokémia és Talajtan, 64(2): 321-338. https://doi.org/ 10.1556/0088.2015.64.2.2

Vysloužilová B., Danková L., Ertlen D., Novák J., Schwartz D., Šefrna L., Delhon C., Berger, J.-F., 2014a. Vegetation history of chernozems in the Czech Republic. Vegetation history and archaeobotany 23: 97-108.

Vysloužilová B., Ertlen D., Šefrna L., Novák T., Virágh K., Rué M., Campaner A., Dreslerová D., Schwartz D., 2014b. Investigation of vegetation history of buried chernozem soil using near-infrared spetroscopy (NIRS). Quaternary International 365: 203-211.

Vysloužilová B., Ertlen D., Schwartz D., Šefrna L., 2016. Chernozem. From concept to classification: a review. AUC Geographica 51: 85-95.

Zádorová T., Penížek V., 2011. Problems in correlation of Czech national soil classification and World Reference Base 2006. Geoderma 167: 54-60.

Zádorová T., Penížek V., Šefrna L., Drábek O., Mihaljevič M., Volf Š., Chuman T., 2013. Identification of Neolithic to Modern erosion-sedimentation phases using geochemical approach in a loess covered sub-catchment of South Moravia, Czech Republic. Geoderma 195: 56-69.

Žínala D., Juřicová A., Zádorová T., Zelenková K., Minařík R.kabala et al, 2019. Mapping soil degradation using remote sensing data and ancillary data: South-East Moravia, Czech Republic. European Journal of Remote Sensing 52, S1: 108122.

Received: October 13, 2019

Accepted: November 8, 2019

Associated editor: B. Glina 